\title{
NATURAL RESOURCES AND ENERGY CONSUMPTION IN EDUCATION INSTITUTIONS; ARTVIN ÇORUH UNIVERSITY CASE
}

\author{
Kadir DOĞANŞAHİN¹, Kazım Onur DEMİRARSLAN* \\ ${ }^{1}$ Artvin Çoruh University, Engineering Faculty, Department of Electrical and Electronics Engineering, Artvin, \\ TURKEY \\ ${ }^{2}$ Artvin Çoruh University, Engineering Faculty, Department of Environmental Engineering, Artvin, TURKEY
}

\begin{tabular}{l} 
Keywords \\
\hline COVID19 Pandemic, \\
Natural Sources, \\
Educational Institutions, \\
Electric Energy, \\
Greenhouse Gases.
\end{tabular}

Abstract

On March 10, 2020, formal education at universities in Turkey has been suspended by the scope of COVID19 measures. In this study, the effects of the pandemic period on natural resources and electricity consumption in educational institutions have been examined. In this study, the consumption of electricity, water, and coal consumptions are discussed. When the realized consumption during the pandemic, when formal education is suspended, and there is no student presence in the campuses, is evaluated as the base consumption values of the institution, the difference between the consumption values before the pandemic and the pandemic period can be interpreted as the consumption realized as a result of formal education activities. Consumption values per student have been calculated by dividing this consumption difference by the number of registered students. Although these values are not scientifically precise, they provide useful information in terms of making approximate consumption estimates according to the changing number of students in the upcoming semesters. The results obtained in the conducted study give an idea about the natural resources and electricity consumption per student in formal education and suggest an approach towards consumption monitoring in different institutions through the use of data from the considered periods.

\section{EĞİTIM KURUMLARINDA DOĞAL KAYNAKLAR VE ENERJİ TÜKETIMİ; ARTVİN ÇORUH ÜNİVERSITESİ ÖRNEĞİ}

\begin{tabular}{|c|c|}
\hline Anahtar Kelimeler & Özet \\
\hline $\begin{array}{l}\text { COVID19 Salgını, } \\
\text { Doğal Kaynaklar, } \\
\text { Eğitim Kurumları, } \\
\text { Elektrik Enerjisi, } \\
\text { Sera Gazları. }\end{array}$ & $\begin{array}{l}10 \text { Mart } 2020 \text { tarihinde Türkiye'de üniversitelerde örgün eğitime COVID19 } \\
\text { önlemleri kapsamında ara verilmiştir. Bu çalışmada pandemi döneminin eğitim } \\
\text { kurumlarında doğal kaynaklar ve elektrik tüketimi üzerindeki etkileri incelenmiştir. } \\
\text { Bu çalışmada elektrik, su ve kömür tüketimleri ele alınmıştır. Pandemi sürecinde, } \\
\text { örgün eğitime ara verildiğinde ve kampüslerde öğrenci bulunmadığında } \\
\text { gerçekleşen tüketim, kurumun temel tüketim değerleri olarak değerlendirildiğinde, } \\
\text { pandemi öncesi tüketim değerleri ile pandemi dönemi arasındaki fark } \\
\text { yorumlanabilir. Örgün eğitim faaliyetleri sonucunda gerçekleşen tüketim kayıtlı } \\
\text { öğrenci sayısına bölünerek öğrenci başına tüketim değerleri hesaplanmıştır. Bu } \\
\text { değerler bilimsel olarak kesin olmasa da ilerleyen dönemlerde değişen öğrenci } \\
\text { sayılarına göre yaklaşı tüketim tahminleri yapmak açısından faydalı bilgiler } \\
\text { vermektedir. Yapılan çalışmada elde edilen sonuçlar, örgün eğitimde öğrenci başına } \\
\text { düşen doğal kaynaklar ve elektrik tüketimi hakkında fikir vermekte ve ele alınan } \\
\text { dönemlere ait veriler kullanılarak farklı kurumlarda tüketimin izlenmesine yönelik } \\
\text { bir yaklaşım önermektedir. }\end{array}$ \\
\hline
\end{tabular}

Alıntı / Cite

Doğanşahin, K., Demirarslan, K.O.,(2021). Natural Resources and Energy Consumption in Education Institutions; Artvin Çoruh University Case, Journal of Engineering and Design, 9(4), 1121-1129.

\footnotetext{
* ilgili yazar / Corresponding author: onurdemirarslan@artvin.edu.tr, +90 4662151040
} 


\begin{tabular}{l|l|l}
\hline Yazar Kimliği / Author ID (ORCID Number) & \multicolumn{3}{|l}{ Makale Süreci / Article Process } \\
\hline K. Doğanşahin, 0000-0002-6763-058X & Başvuru Tarihi / Submission Date & 29.06 .2021 \\
K. O. Demirarslan, 0000-0002-1023-7584 & Revizyon Tarihi / Revision Date & 27.08 .2021 \\
& Kabul Tarihi / Accepted Date & 01.09 .2021 \\
& Yayım Tarihi / Published Date & 20.12 .2021 \\
\hline
\end{tabular}

\section{Introduction}

As a result of the growing world population, developing technology, and rising living standards, dependence on natural resources and energy use has been increasing. The term of natural resources is a definition that corresponds to all resources available in nature and all potentials that can be beneficial for humans in technological, economic, and social conditions (Zaharia and Suteu 2011). Natural resources are divided into two as renewable resources such as earth, water resources, flora, fauna, and forest, non-renewable resources such as fossil fuels and mines (Prepared et al. 2007). Natural resources may be consumed both directly as a primary source and indirectly as intermediate inputs (Ayres and Bergh 2005).

Energy is defined as the ability to do things, do things, and cause changes. Today, energy is needed in all areas of our lives. The energy demand is met from primary energy sources available in nature or secondary energy sources converted from the energy obtained from these sources. Electric energy, which is an indispensable energy type in today's world, is a secondary energy source obtained through the use of various natural resources. It is a sustainable, reliable, and environmentally friendly type of energy with the aspects such as being able to supply through conversions from various resources, ease of transmission and distribution, and not cause solid waste or gas emission during consumption. In the last two decades, global primary energy consumption increased by more than $50 \%$, reaching a value of $162194.44 \mathrm{TWh}$ in 2019 . On the other hand, Electricity consumption increased by more than 80\% and reached 27004.7 TWh in 2019 (BP Statistical Review of World Energy June 2020).

Rising energy consumption, global crises in the supply of natural resources, and rapidly depleting natural resources reserves have led to an increase in economic, sustainability, and environmental concerns in many sectors on a global basis. Therefore, to limit the rise in demand for energy and natural resources, various strategies have been determined to increase efficiency in consumption (Ekins et al. 2016). To achieve success in increasing the efficiency of natural resources and energy consumption, it is very important to comprehend the behavior of consumers in the consumption of these resources. The second-highest share in global primary energy consumption in 2015 belongs to consumption realized in buildings, with 30\% (Industrial consumption has a share of 31\%.) (Global Status Reports 2017). Large institutions such as universities consume large amounts of energy and water daily, as they house many buildings and facilities. These consumptions are made to meet basic needs such as lighting, water supply, and air conditioning. In addition to these, the occupancy levels of buildings in institutions such as universities directly affect their energy and water usage. In addition, in the buildings belonging to institutions such as universities, the number of personnel working and the number of people served directly affects energy and water use (Oyedepo et al. 2015, Chalfoun 2014, Faremi et al. 2019). Understanding the behavior of campus buildings in energy and natural resource consumption is an important prerequisite to understanding how to improve the energy efficiency of building complexes and cities. Although energy efficiency in university campuses has attracted the attention of university administrators and experts in the field in recent years, it has not been taking sufficient attention yet (Guan et al. 2014).

Pandemics occur from time to time throughout the history of humanity and cause the loss of millions of lives and adversely affect the health and mental state of the people (Muhammed and Karataş 2020). Coronavirus disease (COVID-19) is a new epidemic that has been rapidly increasing in cases and deaths since its first definition in December 2019. Its rapid spread, fatality, and inability to treat increase the effect of the disease. The World Health Organization (WHO) identified the disease COVID-19 as "severe acute respiratory syndrome Coronavirus 2 (SARSCoV-2)" and declared it a pandemic in February 2020 (Mizrak and Nur 2021, Islam et al. 2020). After the Turkish Ministry of Health announced the COVID-19 outbreak on March 10, 2020, the Council of Higher Education announced on March 12 that it was suspending formal education at universities. Then, within the scope of COVID19 measures, universities decided to implement distance education with the senate's decisions, and as of May 2021, formal education has not yet begun.

In this study, the energy and natural resource consumption in the Artvin Çoruh University, City, and Seyitler campuses, for two years has been examined. As from the suspension of formal education as a matter of pandemic, academic activities have not been able to realize in the institution buildings for more than a year. During this period, only academic and administrative staff have worked at the institution buildings. Fuel, electricity, and water consumption data for the period March 2019-March 2021 has been obtained from the authorized units within the institution. This data has been divided into two, corresponding to the one year before the suspension of education 
and the one-year period during which education was carried out remotely. By comparing these two data, the effect of formal education on energy and natural resources consumption amount and behavior has been investigated. In addition to the consumption, the amount of gas emissions corresponding to the fuel and electricity consumption has been calculated through various conversions. The study, it is aimed to obtain an approximate value for the amount of consumption and greenhouse gas emitted from the fuel combustions per student by taking into account the number of students belonging to the relevant years. With this value, in the coming years, due to the changes in the number of students, the institution will be able to benefit from how consumption will be affected. Additionally, the findings of the study may be a reference to similar institutions on understanding the behaviors of the consumption of natural resources and energy.

\section{Materials and Methods}

As the study area, two campuses belonging to Artvin Coruh University have been considered. The University is located in Artvin province in the northeast of the Black Sea Region of Turkey.

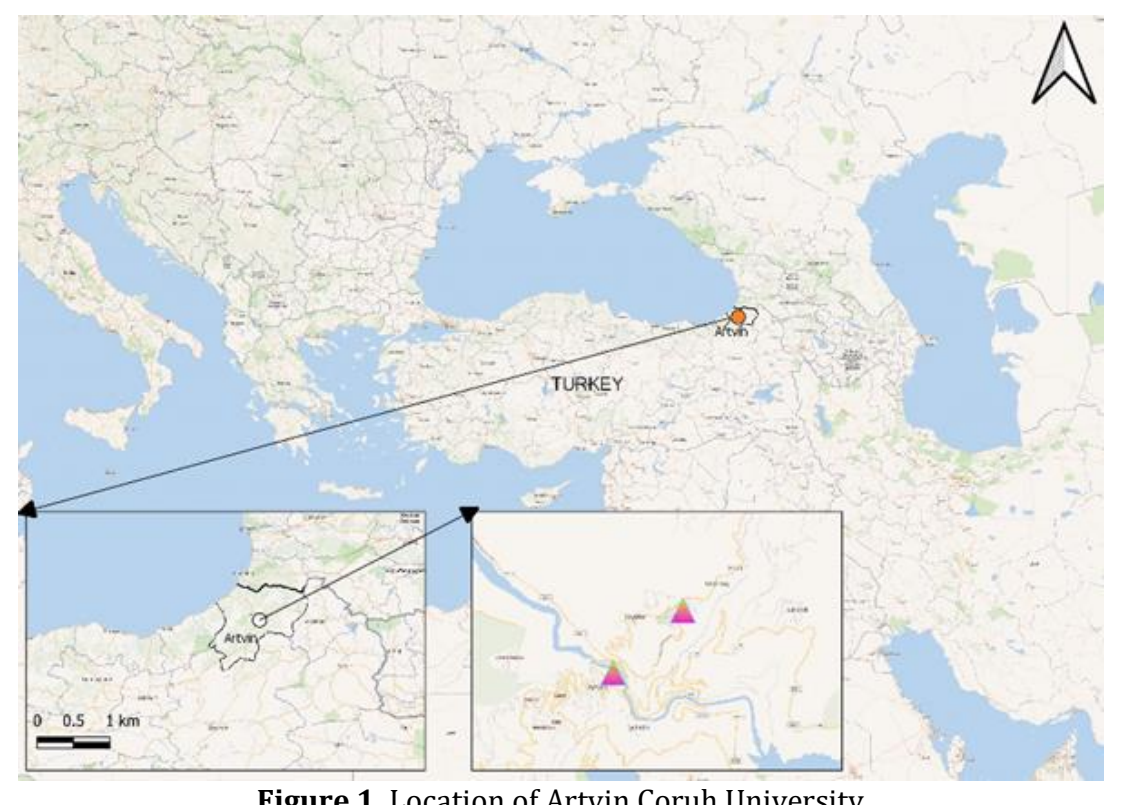

Figure 1. Location of Artvin Çoruh University

City Campus is located at the entrance of Artvin city center. It is located on the riverside of the Coruh River, on 70 decares of land. There are four administrative buildings, four buildings for classrooms, and a library building in the city campus. Seyitler Campus, which is approximately $3 \mathrm{~km}$ away from Artvin city center, is built on 187 decares of land. There are a Rectorate building, two faculty buildings, a vocational school building, two social facility buildings, an administrative building, a central laboratory building, and a workshop building in Seyitler Campus.

In this study, consumption values between March 2019 and March 2021 have been examined. The number of students by the academic years is given in Table- 1 as partitioned to the campuses. The beginning and end dates of the relevant academic years can also be found on the table. In addition, a total of 229 personnel, 45 of which are administrative and 184 academic, are employed in the City campus, and a total of 337 personnel, of which 173 are administrative, and 164 are academic, are employed in the Seyitler campus.

Table 1. Number of students in academic years

\begin{tabular}{|c|c|c|c|}
\hline & 2018-2019 & $2019-2020$ & $2020-2021$ \\
\hline & & (suspended on 12.03.2020) & \\
\hline Seyitler Campus & 2300 & 2289 & 2086 \\
\hline City Campus & 4617 & 4916 & 4110 \\
\hline
\end{tabular}


Within the scope of the study, fuel, water, and electricity consumption data in the campuses has been obtained from the competent units within the university. The data cover the two one-year periods, as one year before and one year after the date when education has been suspended (from 1st of March 2019 to 1st of March 2020 and from 1st of March 2020 to 1st of March 2021).

\section{Results and Discussions}

Electrical energy consumption data have been analyzed separately for Seyitler and the City campus. In the Seyitler campus, electrical energy consumption is realized through external lighting and various electromechanical systems, as well as domestic use. Unlike the Seyitler campus, the city campus has Heating Ventilating and Air Conditioning (HVAC).

Electricity consumption profiles of the Seyitler campus for the terms March 2019 - February 2020 and March 2020 -February 2021 have been given in Fig. 2. The terms when students actively participated in education during the period between March 2019 and February 2020 have been shaded in the figure. It is seen that the electricity consumption behavior remained almost the same in the distance education period but decreased in amount. In Artvin Çoruh University, only two semesters, fall and spring, are offered in an academic year. In summer, there is not any educational activity. As can be seen, the difference in consumption amounts between the two periods decreased in the summer months.

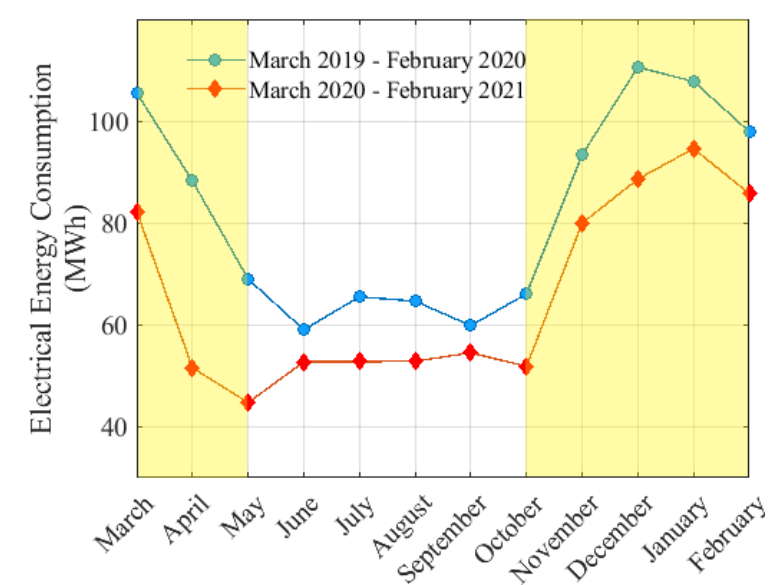

Figure 2. Monthly electrical energy consumption in Seyitler campus

Electricity consumption of the City campus in the terms are considered given in Fig. 3. As can be seen, the consumption profiles of the city campus are quite different from each other. The HVAC system plays an important role in the electrical energy consumption of the city campus. From March 2020 to February 2021, the utilization rate of the HVAC system decreased as most of the classrooms and common areas were not used.

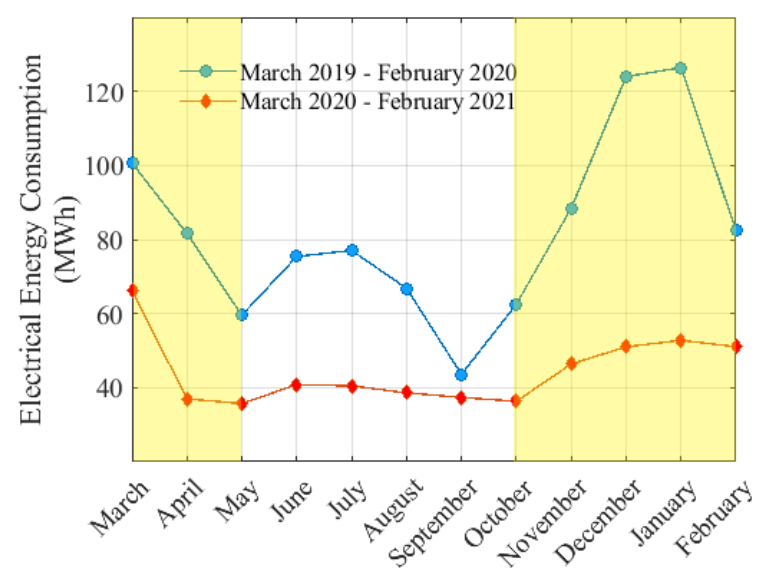

Figure 1. Monthly electrical energy consumption in City campus

In Table 2, annual electrical energy consumption and equivalent $\mathrm{CO}_{2}$ emission values corresponding consumption are given. For the equivalent $\mathrm{CO}_{2}$ emission calculation, the conversion coefficient obtained from a report prepared by a climate research organization for 2019 was used [Brown to Green]. In the report, the conversion factor for Turkey is defined as $0.481 \mathrm{kgCO}_{2} / \mathrm{kWh}$. 
Between March 2020 and February 2021, only academic and administrative staff worked at the university, and formal education activities have not been performed. Considering the amount of consumption realized in the months during the academic period (October-May), it is seen that the electrical energy consumption decreased by $159056 \mathrm{kWh}$ during the pandemic. Due to the fact that training activities could not be carried out in the period of March 2020-February 2021, this difference can be taken as an approximate value for the amount of electrical energy consumption as a result of training activities. When the consumption data of the city campus has been examined with the same approach, it was calculated that the consumption in the academic period decreased by $349261 \mathrm{kWh}$ during the pandemic period. An approximate value can be obtained for the amount of electrical energy consumption per student by dividing these obtained values by the number of registered students in periods considered. As a result of the calculations based on this approach, the annual electrical energy consumption per student has been obtained as $69.31 \mathrm{kWh}$ for the Seyitler campus and $74.38 \mathrm{kWh}$ for the Şehir campus. The annual electrical energy consumption during the pandemic period can be taken as the base consumption of the institution, free from educational activities. Therefore, the equation given below can be used to approximately determine the annual electrical energy consumption amount for the following years.

$E_{(k)}=E_{\text {base }}+N_{\text {reg }(k)} \times E_{s}$

where $E_{k}$ is the annual energy consumption in the year $k, N_{\text {reg(k) }}$, the number of registered students in the year $\mathrm{k}$. $E_{\text {base }}$ is the base annual electricity consumption value and $E_{S}$ is the annual electricity consumption per student.

The equivalent $\mathrm{CO}_{2}$ emissions corresponding to these values are $33.34 \mathrm{kgCO}_{2}$ and $35.78 \mathrm{kgCO}_{2}$, respectively. In the period of March 2020-February 2021, which represents the pandemic process, $508317 \mathrm{kWh}$ less electrical energy consumption was realized compared to the previous year. The equivalent $\mathrm{CO}_{2}$ emission corresponding to this value is $244500 \mathrm{~kg}$.

In Figure 4, monthly water consumption as the total in the city and Seyitler campuses are given. Except for the summer period (June-September), when education is not actively maintained, a significant decrease can be observed in water consumption. Only in February, the water consumption values are close to each other. The reason for this is that February is coming on the midterm break. When the data is evaluated, water consumption decreased by $16082 \mathrm{~m}^{3}$ compared to the year before the pandemic process. Considering the number of registered students in the relevant periods, it can be concluded that water consumption per student is approximately 2.27 $\mathrm{m}^{3}$.

In the study, the amount of fuel used for heating purposes and the use of equivalent greenhouse gas emissions resulting from the use of these fuels have been examined. In the city campus, fuel oil had been using as fuel until the beginning of 2020, but after this date, natural gas has been started to be used. For this reason, it is not possible to compare fuel consumption in the city campus, and only Seyitler Campus has been taken into account. The emission factors given in the Greenhouse Gas Inventory Guidance published by EPA have been used to calculate greenhouse gas emissions (EPA 2016).

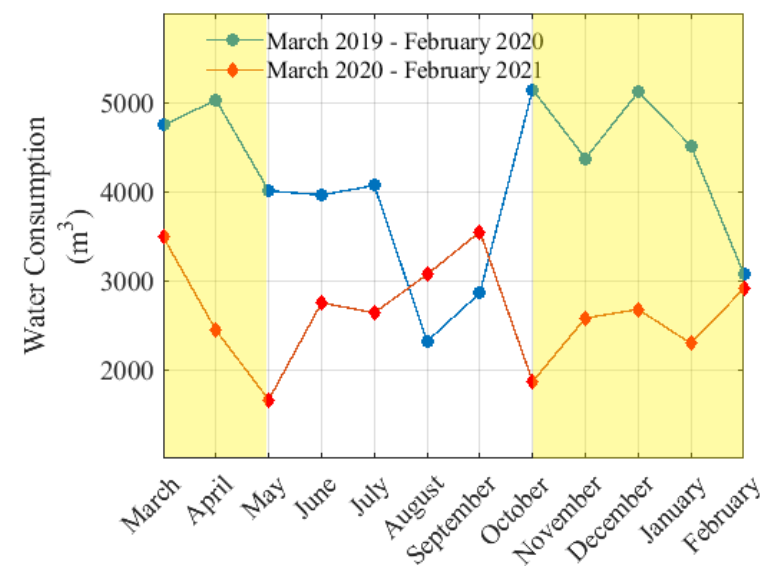

Figure 2. Total water consumption in City and Seyitler campuses

Equivalent $\mathrm{CH}_{4}, \mathrm{CO}_{2}$, and $\mathrm{N}_{2} \mathrm{O}$ emissions from the amount of coal using for heating purposes in Seyitler campus are calculated as pre-pandemic and pandemic periods and are given in Fig. 5-7.

The equation used in emission calculations is given in Equation 2 (EPA 2016). 
Emissions $=$ Fuel $\times \mathrm{EF}_{1}$

Where;

Emissions $=$ Mass of $\mathrm{CO}_{2}, \mathrm{CH}_{4}$, or $\mathrm{N}_{2} \mathrm{O}$ emitted

Fuel $\quad=$ Mass or volume of fuel combusted

$\mathrm{EF}_{1}=\mathrm{CO}_{2}, \mathrm{CH}_{4}$, or $\mathrm{N}_{2} \mathrm{O}$ emission factor per mass or volume unit

Compared to the period before the pandemic, coal consumption decreased by $17 \%$. When the equivalent emissions are examined, it can be clearly understood that the value of equivalent emissions before the pandemic is higher than those in the pandemic period.

When the equivalent amounts of $\mathrm{CO}_{2}$ emissions are examined, it has been calculated as $543348 \mathrm{kgCO}_{2}$ between March 2019 and February 2020, which is taken as the basis for the pre-pandemic period and $450684 \mathrm{kgCO}_{2}$ during the pandemic period. The equivalent $\mathrm{CO}_{2}$ emission calculated for the pandemic period has been $92664 \mathrm{~kg}$ less than the pre-pandemic period. Considering these values, the equivalent $\mathrm{CO}_{2}$ emission per student has been calculated as $40.5 \mathrm{~kg}$.

Table 2. Electrical energy consumption and equivalent $\mathrm{CO}_{2}$ emission in an academic year

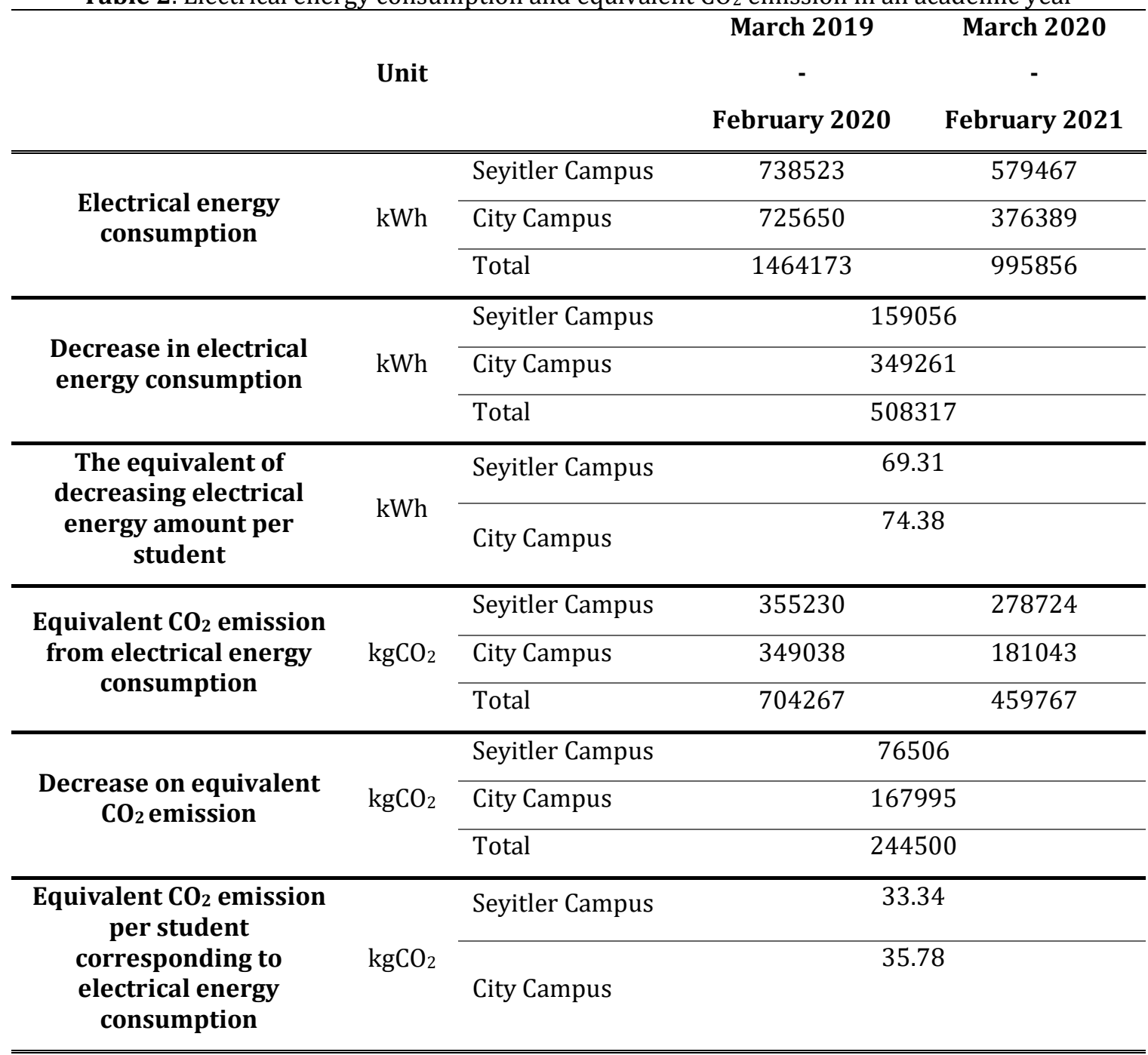




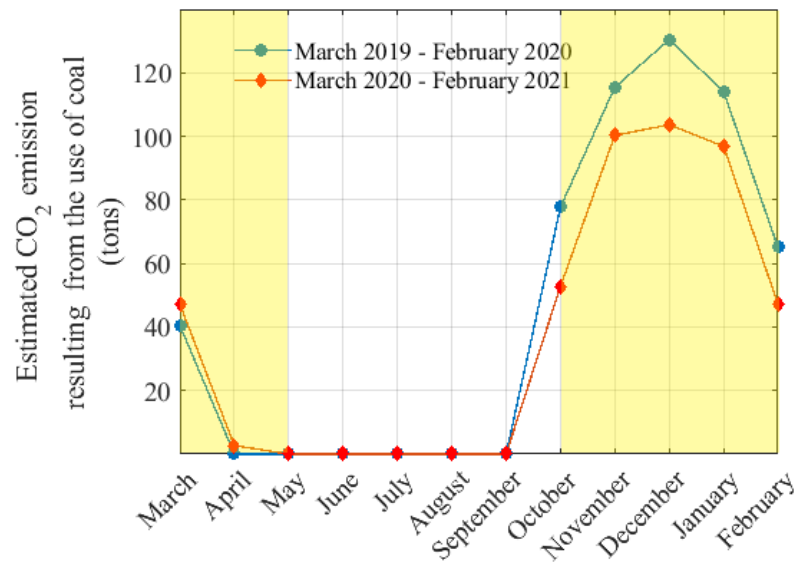

Figure 3. Equivalent $\mathrm{CO}_{2}$ emission from heating purpose coal use in Seyitler campuses

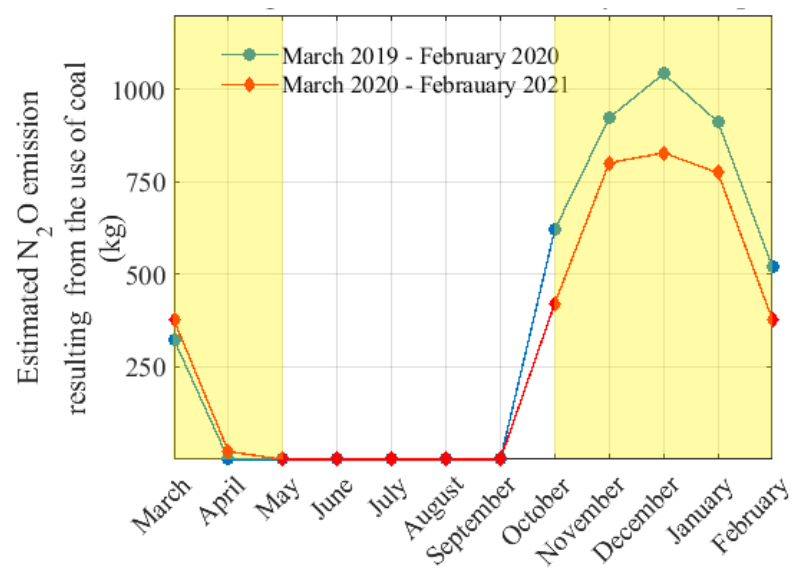

Figure 4. Equivalent $\mathrm{N}_{2} \mathrm{O}$ emission from heating purpose coal use in Seyitler campuses

Regarding the equivalent $\mathrm{N}_{2} \mathrm{O}$ emission, $127686 \mathrm{~kg} \mathrm{~N}_{2} \mathrm{O}$ values have been obtained for the pre-pandemic period and $105910 \mathrm{~kg} \mathrm{~N} 2 \mathrm{O}$ values for the pandemic period. The reduction in the equivalent $\mathrm{N}_{2} \mathrm{O}$ emission value has been calculated as $21776 \mathrm{~kg}$. Based on this value, the equivalent $\mathrm{N}_{2} \mathrm{O}$ emission amount per student is $9.52 \mathrm{~kg} \mathrm{~N}_{2} \mathrm{O}$.

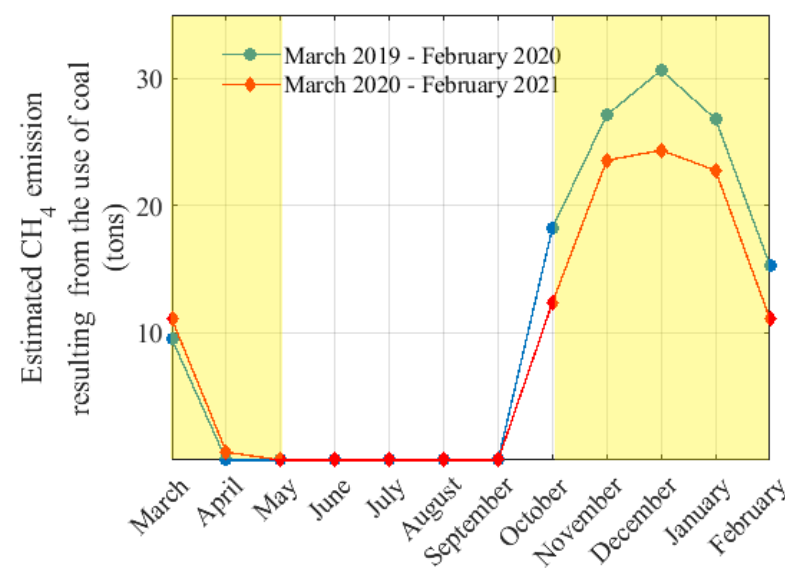

Figure 5. Equivalent $\mathrm{CH}_{4}$ emission from heating purpose coal use in Seyitler campuses

When the equivalent $\mathrm{CH}_{4}$ emissions corresponding to the amount of coal use for heating purposes in the Seyitler campus are examined, the highest values are belong to the December months and have been calculated as 30645 $\mathrm{kgCH}_{4}$ before the pandemic and $24359 \mathrm{kgCH}_{4}$ during the pandemic period. The reduction in equivalent $\mathrm{CH}_{4}$ emission has been calculated as $740 \mathrm{~kg}$. The equivalent $\mathrm{CH}_{4}$ emission per student is $0.32 \mathrm{~kg}$. 


\section{Conclusion (Sonuç)}

The first coronavirus case in Turkey was detected on March 11,2020, when this disease was declared a pandemic by the WHO. From this date, the government has implemented various measures to prevent the rapid spread of the disease. Within the scope of these measures, education in Higher Education institutions was suspended on 12 March 2020, and as of May 2021, formal education has not been started yet. During the while, more than a year, only administrative and academic staff have worked in higher education institutions. This process, due to the pandemic, has provided an important opportunity to get an idea about the share of educational activities in institutions on energy and natural resources consumption.

Based on this idea, March 2019 - February 2020 to represent the pre-pandemic period and March 2020 - February 2021 for the pandemic period have been taken as a basis. Electricity, water, and fuel for heating purposes consumption in these periods have been examined. During the pandemic period, the consumption amounts per student have been calculated by dividing the decreased amounts compared to the consumption in the prepandemic period by the number of registered students in the period they belong to. Although the values obtained are not of a quality that can be taken as a definite coefficient, they can provide an idea in terms of how much annual consumption will be affected according to the number of students in the following years. The annual electrical energy consumption for the period of March 2018 - February 2019 has been calculated by the base consumption amounts and the annual electrical energy consumption values per student defined from the study performed by taking into account the consumption data only for the periods' March 2019 - February 2020 and March 2020 February 2021. In the calculations, the number of registered students for the relevant period has been considered. Between the consumption calculated over the proposed approach in the study and the actual consumption, it was 5.4\% for the Seyitler campus and 5.3\% for the City campus. The values obtained within the scope of the study will benefit the authorities in the planning studies, monitoring of consumption, efficiency, and savings studies to be carried out within the institution.

\section{Acknowledgment}

This study was supported by Artvin Çoruh University. We are thankful to Artvin Çoruh University for share to their data.

\section{Conflict of Interest}

No conflict of interest was declared by the authors.

\section{References (Kaynaklar)}

Ayres, R.U. and van den Bergh, J.C.J.M. 2005. A Theory of Economic Growth with Material/Energy Resources and Dematerialization: Interaction of Three Growth Mechanisms, Ecological Economics, 55, 96-118.

Bernard, L. 2020. BP statistical review of world energy 2020,https://www.bp.com/content/dam/bp/businesssites/en/global/corporate/pdfs/energy-economics/statistical-review/bp-stats-review-2020-full-report.pdf, (05.05.2021).

Brown to Green 2019. Berlin: Climate Transparency, 2019. https://www.climate-transparency.org/g20-climateperformance/g20report2019, (05.05.2021).

Ekins, P. Hughes, N. Brigenzu, S. Arden Clark, C. Fischer-Kowalski, M. Graedel, T. Hajer, M. Hashimoto, S. et al. 2016. Resource Efficiency: Potential and Economic Implications. Report of the International Resource Panel, United Nations Environment Program (UNEP),

Paris, https://www.resourcepanel.org/sites/default/files/documents/document/media/resour(05.05.2021)ce_efficiency_repo rt_march_2017_web_res.pdf, (05.05.2021).

EPA 2016, U.S. EPA Center for Corporate Climate Leadership, Greenhouse Gas Inventory Guidance Direct Emissions from Stationary Combustion Sources, https://www.epa.gov/sites/production /files/2016-03/documents/stationaryemission s_3_2016.pdf (27.05.2021).

Global Status $\quad$ Report $2017 . \quad$ UN https://www.worldgbc.org/sites/default/files/UNEP\%20188_GABC_en\%20\%28web\%29.pdf, (05.05.2021).

Islam, A. Khan, F. Imtiaz, S. and Ahmed, S. 2020. Journal of Loss Prevention in the Process Industries How can process safety and a risk management approach guide pandemic risk management? J. Loss Prev. Process Ind. 68, 104310. https://doi.org/10.1016/j.jlp.2020.104310.

Mizrak, B. and Nur, E. 2021. The experiences of pregnant women during the COVID-19 pandemic in Turkey : A qualitative study. Women and Birth, 34, 162-169. https://doi.org/10.1016/j.wombi.2020.09.022.

Muhammed, A. Karataș, K. 2020. Psychological Effects of COVID-19 Pandemic on Society and Its Reflections on Education. Turkish Stud. 15, 1-13. https://doi.org/10.7827/TurkishStudies.44336. 
OECD, 2008. Natural Resources of Natural Resources of. Nat. Resour. Pro-Poor Growth Econ. Polit. OECD, 2933,https://read.oecd-ilibrary.org/development/natural-resources-and-pro-poor-growth_9789264060258en?_ga=2.242112577.257257097.1624964232-1010423968.1624964232\#page3, (05.05.2021).

Oyedepo, S.O. Leramo, R.O. Adekeye, T. Kilanko, O. Babalola, O.P. Balogun, A.O. Akhibi, M.O. 2015. A Study on Energy Demand and Consumption in Covenant University, Ota, Nigeria. Int. Conf. African Dev. Issues, 203-211.

Yllmaz İnce, E. Kabul, A. and Diler, İ. 2020. Distance education in higher education in the COVID-19 pandemic process: A case of Isparta Applied Sciences University. International Journal of Technology in Education and Science, 4(4), 343-351.

Zaharia, C., Suteu, D., 2011. The Natural Resources and Sustainable Development. Cercetări Agronomice în Moldova, XLIV, 1(145), 93-101. 